\title{
Length-weight relationships of ten tropical finfish species from north eastern Arabian Sea, India
}

\author{
G. B. Purushottama \\ K. V. Akhilesh \\ B. B. Chavan \\ B. N. Katkar | Thakurdas \\ V.V. Singh
}

ICAR-Central Marine Fisheries Research Institute, Kochi, Kerala, India

\section{Correspondence}

G. B. Purushottama, ICAR-Central Marine Fisheries Research Institute, Kochi, Kerala, India.

Email: puru44@gmail.com

\begin{abstract}
Summary
The length weight relationships (LWRs) of ten tropical finfish species from north eastern Arabian Sea, India were studied. Specimens were caught using a wide range of fishing gear mainly trawl nets $(20-25 \mathrm{~mm})$, dol nets or bag nets $(20-40 \mathrm{~mm})$ and gill nets $(80-270 \mathrm{~mm}$ ) operated in Maharashtra maritime waters during 2012-2016. The specimens were measured for total length, and weight, then dissected and the sex confirmed. Previously unavailable in FishBase, the detailed LWR of Polydactylus mullani is reported for the first time. Maximum total lengths presented for six species in this study are new records. The existence of a differential growth between male and female was confirmed for five species, which was not known earlier. The LWR data will be useful for deriving future sustainable management and conservation strategies.
\end{abstract}

\section{1 | INTRODUCTION}

Maharashtra state in India along north eastern Arabian Sea has 720 km long coastline stretched across six maritime districts viz., Palghar, Thane, Greater Mumbai, Raigad, Ratnagiri and Sindhudurg. With an average annual marine fish landings of 3.16 lakh $t$ during 2012-16, Maharashtra is one of the major marine fish producing states ranking 6th in the country after Andhra Pradesh, Karnataka, Kerala, Tamil Nadu and Gujarat (CMFRI, 2016). The annual marine fishery potential of the State in the Exclusive Economic Zone (EEZ) is estimated at 6.5 lakh $t$ while the long term potential yield (LTPY) based on the maximum annual landings up to $90 \mathrm{~m}$ depth during 2001-2010 is estimated at 5.2 lakh t (CMFRI, 2010a). There are 17,362 crafts in the fishery of which 13,016 were mechanized, 1,563 motorized and non-motorized (2,783). This maritime State with 456 marine fishing villages and 152 fish landing centres supports the livelihood of more than 0.38 million fisher folk (CMFRI, 2010b). The fisheries sector share is $0.3 \%$ of the Gross domestic product (GDP) of
State. India has exported 9,45,892 MT of seafood worth US\$ 4.7 billion during $2015-16$, compared to previous year $10.02 \%$ quantity of seafood was less (MPEDA, 2016). Hence, updated information on the fish stocks is of utmost importance to manage fishery resources in a manner that is ecologically sustainable and yet economically viable and socially acceptable.

The fishery of Sciaenids, Threadfin breams, Catfishes, Pomfrets, Carangids, Groupers, Lizard fishes, Threadfins, Flat fishes, False trevally, and Goat fishes are mainstay in the total fish production of the State, invariably contributing 9.0\%, 4.4\%, 4.1\%, 2.3\%, 0.95\%, 0.9\%, $0.83 \%, 0.5 \%, 0.26 \%$, and $0.35 \%$ respectively (CMFRI, 2016). These groups have been and continue to be exploited by a wide range of traditional and mechanized fishing gears in the State.

Length-weight relationships (LWRs) parameters $(a, b)$ are important for fishery stock assessments and populations (Ricker, 1968), allows the conversion of length into weight and vice versa (Le Cren, 1951), indicators to ascertain the status of fish, such as their nutrition, reproduction and health (Park et al., 2016) and also LWRs allows biometric 
TAB LE 1 Length- weight relationships for ten tropical finfish species sampled during 2012 -2016 from north eastern Arabian Sea, India

\begin{tabular}{|c|c|c|c|c|c|c|c|c|c|c|}
\hline Family/Species & Sex & $N$ & $\begin{array}{l}\text { TL range } \\
(\mathrm{cm})\end{array}$ & BW range (g) & \multicolumn{6}{|c|}{ Regression parameters } \\
\hline \multicolumn{11}{|l|}{ Scieanidae } \\
\hline \multirow{2}{*}{$\begin{array}{l}\text { Protonibea } \\
\text { diacanthus }\end{array}$} & M & 391 & $20.3-40.2$ & $75.0-629$ & 0.008049 & $0.0066-0.0099$ & 3.1 & $3.00-3.12$ & 0.031 & .987 \\
\hline & $\mathrm{F}$ & 493 & $19.8-165$ & $71.0-22,900$ & 0.008808 & $0.0058-0.0134$ & 3.0 & $2.92-3.15$ & 0.056 & .991 \\
\hline \multirow{3}{*}{$\begin{array}{l}\text { Otolithoides } \\
\text { biauritus }\end{array}$} & M & 289 & $17.9-143.5$ & $35.0-14,180$ & 0.005969 & $0.0051-0.0070$ & 3.0 & $2.98-3.07$ & 0.023 & .991 \\
\hline & $\mathrm{F}$ & 273 & $12.5-117.0$ & $66.0-8,500$ & 0.008416 & $0.0076-0.0093$ & 2.9 & $2.89-2.95$ & 0.013 & .996 \\
\hline & C & 562 & $12.5-143.5$ & $35.0-14,180$ & 0.009158 & $0.0085-0.0099$ & 2.9 & $2.88-2.92$ & 0.010 & .994 \\
\hline \multicolumn{11}{|l|}{ Cynoglossidae } \\
\hline \multicolumn{11}{|l|}{ Serranidae } \\
\hline \multirow{3}{*}{$\begin{array}{l}\text { Epinephelus } \\
\text { diacanthus }\end{array}$} & M & 208 & $16.6-39.5$ & $69.0-832$ & 0.032377 & $0.0246-0.0426$ & 2.7 & $2.64-2.81$ & 0.044 & .949 \\
\hline & $\mathrm{F}$ & 1,002 & $12.0-41.9$ & $21.0-957$ & 0.014946 & $0.0135-0.0166$ & 3.0 & $2.94-3.13$ & 0.017 & .969 \\
\hline & C & 1,210 & $16.6-41.9$ & $21.0-957$ & 0.016172 & $0.0147-0.0178$ & 2.9 & $2.92-2.98$ & 0.016 & .967 \\
\hline \multicolumn{11}{|l|}{ Ariidae } \\
\hline \multirow{3}{*}{$\begin{array}{l}\text { Osteogeneiosus } \\
\text { militaris }\end{array}$} & $M$ & 582 & $16.6-43.0$ & $36.0-695$ & 0.010550 & $0.0087-0.0128$ & 2.9 & $2.89-3.00$ & 0.029 & .950 \\
\hline & $F$ & 478 & $17.7-48.5$ & $45.0-825$ & 0.010570 & $0.0087-0.0128$ & 2.9 & $2.89-3.00$ & 0.028 & .959 \\
\hline & C & 1,060 & $16.6-48.5$ & $36.0-825$ & 0.010115 & $0.0089-0.0115$ & 3.0 & $2.92-3.16$ & 0.019 & .961 \\
\hline $\begin{array}{l}\text { Nemapteryx } \\
\text { caelata }\end{array}$ & M & 236 & $28.3-48.3$ & $227-1,258$ & 0.001769 & $0.0008-0.0040$ & 3.5 & $3.28-3.73$ & 0.110 & .967 \\
\hline \multirow{3}{*}{$\begin{array}{l}\text { Nemipterus } \\
\text { randalli }\end{array}$} & M & 1,123 & $8.4-23.5$ & $9.0-168$ & 0.020414 & $0.0187-0.0223$ & 2.9 & $2.82-2.88$ & 0.016 & .970 \\
\hline & $\mathbf{F}$ & 410 & $10.4-24.1$ & $18.0-173$ & 0.019135 & $0.0164-0.0223$ & 2.9 & $2.82-2.93$ & 0.028 & .964 \\
\hline & C & 1,533 & $8.4-24.1$ & $9.0-173$ & 0.020086 & $0.0186-0.0217$ & 2.9 & $2.80-2.86$ & 0.014 & .968 \\
\hline \multicolumn{11}{|l|}{ Polynemidae } \\
\hline \multirow{3}{*}{$\begin{array}{l}\text { Polydactylus } \\
\text { mullani }\end{array}$} & M & 609 & $11.3-22.2$ & $24.0-135$ & 0.009556 & $0.0075-0.0122$ & 3.0 & $2.96-3.14$ & 0.044 & .926 \\
\hline & $\mathbf{F}$ & 279 & $12.1-28.5$ & $26.0-248$ & 0.013849 & $0.0104-0.0184$ & 2.9 & $2.83-3.02$ & 0.048 & .960 \\
\hline & C & 888 & $11.3-28.5$ & $24.0-248$ & 0.010723 & $0.0091-0.0126$ & 3.0 & $2.95-3.07$ & 0.029 & .951 \\
\hline \multicolumn{11}{|l|}{ Synodontidae } \\
\hline \multirow[t]{3}{*}{ Saurida tumbil } & $M$ & 548 & $11.3-45.5$ & $21.0-761$ & 0.008894 & $0.0072-0.0110$ & 2.9 & $2.87-3.00$ & 0.033 & .944 \\
\hline & $\mathbf{F}$ & 424 & $19.4-54.0$ & $49.0-1,113$ & 0.005789 & $0.0047-0.0072$ & 3.1 & $3.13-3.23$ & 0.032 & .958 \\
\hline & $\mathrm{C}$ & 972 & $11.3-54.0$ & 21.0-1,113 & 0.007040 & $0.0061-0.0081$ & 3.0 & 2.97-3.05 & 0.022 & .955 \\
\hline
\end{tabular}

$N$, sample size; M, male; F, female; C, combined sex; TL, total lengths in $\mathrm{cm}$; BW, body weight in g; $a$ and $b$, parameters of length weight relationship; CL, confidence limit; SE $(b)$, standard error of slope $b ; r^{2}$, coefficient determination. Bold, maximum total lengths exceeding those in FISHBASE.

and morphological comparisons between different fish species in the same taxonomic group, or between fish populations from different regions or periods (Zhang et al., 2016), however, many fish species are still not available in FishBase (Froese \& Pauly, 2017). Therefore, the present study presents the LWR of ten demersal finfish species from the north eastern Arabian Sea, India. 


\section{2 | MATERIAL AND METHODS}

\section{1 | Study area and sampling}

Length and weight data for 5 years, weekly fish sampling was from the commercial catch at fish landing centres located around Mumbai, Maharashtra, India (Sassoon dock [18-54-42.43ํ․ $\left.72-49-33.16^{\circ} \mathrm{E}\right]$, New Ferry Wharf [18-57-28.85 $\left.\mathrm{N}, 72-51-02.73^{\circ} \mathrm{E}\right]$, Pachu bunder $\left[19-21-2.88^{\circ} \mathrm{N}, \quad 72-48-24.12^{\circ} \mathrm{E}\right]$, Satpati $\left[19-43-30.75^{\circ} \mathrm{N}\right.$, $72-42-08.30^{\circ} \mathrm{E}$ ) during 2012-2016. Lengths and weights (whole wet body weight) were measured to the nearest $0.1 \mathrm{~cm}$ and $0.01 \mathrm{~g}$, respectively using an electronic balance (Axpert, India). Measurement of total body length (TL) was used for fishes with different body shapes. Fishes were identified to species level and validated following FishBase (Froese \& Pauly, 2016). Immediately thereafter labelled the plastic boxes containing different fishes in the ice at the ratio of 1:2 was transported to the laboratory where the specimens were dissected and the sex confirmed.

\subsection{Data analysis}

The length-weight relationships of male, female and combined sex were established using linear regression analysis (least squares method). Parameters $a$ and $b$ of the length-weight relationships were estimated using the equation proposed by Le Cren (1951): $W=a \times L^{b}$. After logarithmic transformation of length and weight data, this equation may be expressed as: $\log W=\log a+b \log L$.where, $W$ is the weight of the fish in grams and $L$ is the total length of the fish in $\mathrm{cm}$, where $a$ is the intercept of the regression curve (coefficient related to body form) and $b$ is the regression coefficient (exponent indicating isometric growth; Froese, 2006).

\section{3 | RESULTS}

We sampled a total of 9,169 fish specimens representing ten species, ten genera and seven families and estimated LWR parameters along with the descriptive statistics are given in Table 1. Sample sizes ranged from $461 \mathrm{~N}$. caelata individuals to $1,533 \mathrm{~N}$. randalli. Coefficient of determination $R^{2}$ ranged from .951 for $P$. mullani to .994 for $P$. diacanthus. The $b$ values ranged from 2.9 for $P$. diacanthus, E. diacanthus, $P$. tenuispinis, N. randalli to 3.6 for N. caelata and the mean value of $b$ was 3.1 (Table 1). Values of parameter $b$ remained within the expected range of $2.5<b<3.5$ (Froese, 2006), however, for N. caelata $b$ was $>3.5$ and these parameters varied among species. Three species were following allometric growth $b>3$ (the fish grows faster in weight than in length), four were $b<3$ (the fish grows faster in length than in weight) and three were $b=3$ (growth is isometric).

\section{4 | DISCUSSION}

Maximum total lengths of six of the species (O. militaris, P. tenuispinis, N. caelata, N. randalli, P. mullani, and S. tumbil) exceeded the
FishBase data. The length range of $P$. diacanthus, O. militaris, $P$. tenuispinis, E. diacanthus, P. mullani, and C. arel had no previous record in FishBase. The $b$ values for LWR estimates in the present study for O. militaris, N. caelata, C. arel, and S. tumbil are 3.0, 3.6, 3.4, and 3.0 and did not fall within the $95 \%$ confidence intervals of Bayesian predictions made for these four species, however, N. randalli (2.9) was within the range of Bayesian predictions made for this species following the method identified in FishBase (Froese \& Pauly, 2017; Froese, Thorson, \& Reyes, 2013) and for remaining five species (P. diacanthus, O. militaris, P. tenuispinis, E. diacanthus, P. mullani) Bayesian predictions not available. LWRs of $P$. mullani was not yet available in FishBase (Froese \& Pauly, 2017) and present study represents the first reference on LWR of this species. The differential growth pattern between male and female for $P$. diacanthus, $C$. arel, E. diacanthus, $O$. biauritus, and P.tenuispinis was confirmed with separate LWR estimates, which were not known earlier. The new TLmax have been included in this study and thus the LWRs for O. biauritus, O. militaris, N. caelata, P. tenuispinis, N. randalli, and S. tumbil are reported in the paper. This study provides basic information on the LWRs of these commercial important demersal finfishes, which could be useful for sustainable management and for further biological research in the region.

\section{ACKNOWLEDGEMENTS}

Authors are thankful to the Director, ICAR-CMFRI for the support and the facilities provided. Swapnil Tandel, Bala Madhgut and Dhanashree Bagade is acknowledged for the support in field and laboratory.

\section{ORCID}

G. B. Purushottama iD http://orcid.org/0000-0001-5303-9943

\section{REFERENCES}

CMFRI. (2010a). Annual report 2009-10 (pp. 169). Cochin: Central Marine Fisheries Research Institute.

CMFRI. (2010b). Marine fisheries census: Maharashtra part-II (9) (pp. 326). Cochin: Central Marine Fisheries Research Institute.

CMFRI. (2016). Annual report 2015-16 (pp. 294). Cochin: Central Marine Fisheries Research Institute.

Froese, R. (2006). Cube law, condition factor and weight-length relationships: History, meta-analysis and recommendations. Journal of Applied Ichthyology, 22, 241-253.

Froese, R., \& Pauly, D. (2016). Fishbase. World Wide Web electronic publication. Retrieved from http://www.fishbase.org . (accessed on 20 June 2016).

Froese, R., \& Pauly, D. (Eds.) (2017). FishBase. World Wide Web electronic publication. Retrieved from http://www.fishbase.org Version (02/2017) (accessed on 1 June 2017).

Froese, R., Thorson, J., \& Reyes, R. B. Jr (2013). A Bayesian approach for estimating length-weight relationships in fishes. Journal of Applied Ichthyology, 30, 1-7.

Le Cren, E. D. (1951). The length-weight relationship and seasonal cycle in gonad weight and condition in the perch (Perca fluviatilis). Journal of Animal Ecology, 20, 201-219.

MPEDA. (2016). Annual report-2015-16 (pp. 262). Cochin: Ministry of Commerce and Industry, Govt. of India. 
Park, S. H., Yoon, J. D., Kim, J. H., Lee, J. W., Baek, S. H., \& Jang, M. H. (2016). Length-weight relationships of fifteen endemic freshwater fishes in South Korea. Journal of Applied Ichthyology, 32, 158-159.

Ricker, W. E. (1968). Methods for assessment of fish production in freshwaters, IBP Handbook No.3. Oxford, UK: Blackwell Scientific Publications, pp. 313.

Zhang, Z. M., Xie, C. X., Ding, H. P., Ma, X. F., Liu, C. J., \& Guo, Y. (2016). Length-weight and length-length relationships of seven fish species from the lli River and tributaries, northwest China. Journal of Applied Ichthyology, 32, 153-155.
How to cite this article: Purushottama GB, Akhilesh KV, Chavan BB, Katkar BN, Thakurdas, Singh VV. Length-weight relationships of ten tropical finfish species from north eastern Arabian Sea, India. J Appl Ichthyol. 2017;00:1-4. https://doi. org/10.1111/jai.13530 